\title{
Investigation on Mechanical Properties of Low Calcium Fly Ash and Slag based Geopolymer Concrete
}

\author{
T Srinivas \\ Research Scholar, Department of Civil Engineering, \\ JNTUH, Hyderabad, India -500085 \\ N V Ramana Rao \\ Professor, Department of Civil Engineering, \\ JNTUH, Hyderabad, India -500085 \\ G.Shiva Pavani \\ Post Graduate Student, Department of Civil Engineering, \\ GRIET, Hyderabad-500090
}

\begin{abstract}
Geopolymer is emerging as future cement as it not only meets the critical properties of cement but also falls under category of sustainability. An objective of this paper is aimed to investigate the compressive, tensile and flexural strength of low calcium fly ash (Class-F) and slag based geopolymer concrete for G50 which is equivalent to M50 grade of concrete. The alkaline solution used for the present study is combination of sodium silicate (Na2Sio3) and sodium hydroxide ( $\mathrm{NaOH}$ in the range of 12 to 18 molarity). The ratio of $\mathrm{Na} 2 \mathrm{SiO} 3$ to $\mathrm{NaOH}$ is 2.5 and $\mathrm{SiO} 2$ to $\mathrm{Na2O}$ is $2.09 \mathrm{has}$ been used since the compressive strength is maximum at these ratios. The test specimens were cast and after one day rest period, half of the specimens were cured in an oven at $60^{\circ} \mathrm{C}$ for 24 hours and the remaining period cured in sun light until the testing is done and remaining half of the specimens were ambient cured. The specimens were tested on $3 \mathrm{rd}$, 7 th and 28th day according to codal procedures. The comparative study is done among oven curing, ambient curing and contol mix for compressive, tensile and flexural strength of concrete. From the test results it is observed that the compressive strength of G50 grade of geopolymer concrete was slightly increased compared to control mix of M50 grade and there is a slightly lower result in case of split tensile strength but there is no much variation in flexural strength.
\end{abstract}

Keywords: Geopolymer Concrete, Oven Curing, Compressive, Tensile and Flexural Strength

\section{INTRODUCTION}

After wood, concrete is the most often used material by the community. Concrete is conventionally produced by using the ordinary Portland cement (OPC) as the primary binder. The environmental issues associated with the production of OPC are well known. The amount of the carbon dioxide released during the manufacture of OPC due to the calcination of limestone and combustion of fossil fuel is in the order of one ton for every ton of OPC produced. In addition, the amount of energy required to produce OPC is only next to steel and aluminium.

On the other hand, the abundance and availability of fly ash worldwide create opportunity to utilise this by-product of burning coal, as partial replacement or as performance enhancer for OPC. Fly ash in itself does not possess the binding properties, except for the high calcium or ASTM Class C fly ash. However, in the presence of water and in ambient temperature, fly ash reacts with the calcium hydroxide during the hydration process of OPC to form the calcium silicate hydrate (C-S-H) gel. This pozzolanic action happens when fly ash is added to OPC as a partial replacement or as an admixture. The development and application of high volume fly ash concrete, which enabled the replacement of OPC up to $60-65 \%$ by mass (Malhotra 2002; Malhotra and Mehta 2002), can be regarded as a landmark in this attempt. 
In another scheme, pozzolanas such as blast furnace slag and fly ash may be activated using alkaline liquids to form a binder and hence totally replace the use of OPC in concrete. In this case the main constituents to be activated with high alkaline solution are mostly the silicon and the aluminium present in the by-product material such as low calcium fly ash (ASTM Class F) (Palomo, Grutzeck et al. 1999). The binder produced in this case is due to polymerisation. Several research publications were available regarding geopolymer pastes and geopolymer coating materials (Davidovits 1991; Davidovits 1994; Davidovits et al. 1994; Balaguru, Kurtz et al. 1997; van Jaarsveld, van Deventer et al. 1997; Balaguru 1998; van Jaarsveld, van Deventer et al. 1998; Davidovits 1999; Kurtz, Balaguru et al. 1999; Palomo, Grutzeck et al. 1999; Barbosa, MacKenzie et al. 2000). However, not a great deal was known regarding using the geopolymer technology to make fly ash based geopolymer concrete. The research reported in this paper is dedicated to investigate the process of making fly ash and slag based geopolymer concrete and the short-term engineering properties of the fresh and hardened concrete.

\section{MATERIALS}

\subsection{Ordinary Portland Cement}

In the experimental investigations, 53-grade of ordinary Portland cement of Ultra-tech Brand is used. The cement thus procured was tested for physical properties in accordance with the IS: 4031-1968 and found to be conforming various specifications of IS 12629-1987.

Table-1: Chemical Composition of Cement (Source: www.cement.org)

\begin{tabular}{|c|c|c|}
\hline S.NO. & Constituent & Percentage \\
\hline 1 & Cao & 63.70 \\
\hline 2 & $\mathrm{SiO}_{2}$ & 22.00 \\
\hline 3 & $\mathrm{Al}_{2} \mathrm{O}_{3}$ & 4.25 \\
\hline 4 & $\mathrm{Fe}_{2} \mathrm{O}_{3}$ & 3.40 \\
\hline 5 & $\mathrm{MgO}$ & 1.50 \\
\hline 6 & $\mathrm{SO}_{3}$ & 1.95 \\
\hline
\end{tabular}

Table 2: Physical Properties of Ordinary Portland Cement of 53 Grade

\begin{tabular}{|c|c|c|c|}
\hline S.No & $\begin{array}{c}\text { Characteristics } \\
\text { /Properties }\end{array}$ & $\begin{array}{c}\text { Test } \\
\text { Results }\end{array}$ & $\begin{array}{c}\text { Requirements as per } \\
\text { IS 12269-1987 }\end{array}$ \\
\hline 1 & Normal consistency & $33 \%$ & ---- \\
\hline 2 & Specific gravity & 3.01 & 3.0 to 3.2 \\
\hline 3 & $\begin{array}{c}\text { Setting time } \\
\text { Initial setting time } \\
\text { Final setting time }\end{array}$ & $\begin{array}{c}35 \mathrm{~min} \\
550 \mathrm{~min}\end{array}$ & $\begin{array}{c}\text { Not less than } 30 \text { minutes } \\
\text { Not more than } 600 \\
\text { minutes. }\end{array}$ \\
\hline 4 & Soundness-Lechatlier method & 1.55 & \begin{tabular}{c} 
Not more than $10 \mathrm{~mm}$ \\
\hline 5
\end{tabular} \\
\hline $\begin{array}{c}\text { Fineness of cement by sieving through sieve No.9(90 microns) for a } \\
\text { period of } 15 \text { minutes }\end{array}$ & $4 \%$ & $<10 \%$ \\
\hline 6 & Compressive strength at 28 days & 55 & --- \\
\hline
\end{tabular}

2.2 Fine Aggregate

In the present investigation, fine aggregate used is obtained from local sources. The sand is made free from clay matter, silt, and organic impurities and sieved on $4.75 \mathrm{~mm}$ IS sieve. The physical properties of fine aggregate like specific gravity, bulk density, gradation and fineness modulus are tested in accordance with IS: 2386 and the results are shown in table 3, 4 and 5. Grain size distribution of sand shows it is close to Zone II of IS 383-1970. 
Table 3: Physical Properties of Fine Aggregate

\begin{tabular}{|c|c|c|c|}
\hline S.No & \multicolumn{2}{|c|}{ Properties } & Test Results \\
\hline 1 & \multicolumn{2}{|c|}{ Specific Gravity } & 2.63 \\
\hline \multirow{2}{*}{2} & \multirow{2}{*}{ Bulk Density } & Loose & $1597 \mathrm{Kg} / \mathrm{m} 3$ \\
\hline & & Compacted & $1725 \mathrm{Kg} / \mathrm{m} 3$ \\
\hline
\end{tabular}

Table 4 : Sieve Analysis of Fine Aggregate

Quantity of fine aggregate for sieve analysis $=1000 \mathrm{gms}$

\begin{tabular}{|c|c|c|c|c|c|}
\hline S.No & $\begin{array}{c}\text { IS } \\
\text { Sieve } \\
\text { No }\end{array}$ & $\begin{array}{c}\text { Weight } \\
\text { Retained } \\
(\mathrm{gm})\end{array}$ & $\begin{array}{c}\text { Percentage } \\
\text { Weight } \\
\text { Retained }\end{array}$ & $\begin{array}{c}\text { Cumulative } \\
\text { Percentage } \\
\text { Weight } \\
\text { retained }\end{array}$ & $\begin{array}{c}\text { Percentage } \\
\text { Weight } \\
\text { passed }\end{array}$ \\
\hline 1 & $40 \mathrm{~mm}$ & 0 & 0 & 0 & 100 \\
\hline 2 & $20 \mathrm{~mm}$ & 0 & 0 & 0 & 100 \\
\hline 3 & $10 \mathrm{~mm}$ & 0 & 0 & 0 & 100 \\
\hline 4 & $4.75 \mathrm{~mm}$ & 3.5 & 0.35 & 0.35 & 99.65 \\
\hline 5 & $2.36 \mathrm{~mm}$ & 15 & 1.5 & 1.85 & 98.15 \\
\hline 6 & $1.18 \mathrm{~mm}$ & 96 & 9.6 & 54.45 & 45.55 \\
\hline 7 & $600 \mu$ & 430 & 43 & 96.5 & 3.5 \\
\hline 8 & $300 \mu$ & 420.5 & 42.05 & 100 & 0 \\
\hline 9 & $150 \mu$ & 35 & 3.5 & 264.6 & \\
\hline & \multicolumn{7}{|c|}{ Total }
\end{tabular}

Fineness modulus of fine aggregate $=$ Cumulative percentage retained/100

$$
=264.6 / 100=2.65
$$

Table 5 :IS Grading Requirements for Fine Aggregate

\begin{tabular}{|c|c|c|c|c|}
\hline Sieve & \multicolumn{4}{|c|}{ Percentage by weight passing sieves IS:383-1970 } \\
\hline IS & $\begin{array}{c}\text { Grading } \\
\text { Zone I }\end{array}$ & $\begin{array}{c}\text { Grading } \\
\text { Zone II }\end{array}$ & $\begin{array}{c}\text { Grading } \\
\text { Zone III }\end{array}$ & $\begin{array}{c}\text { Grading } \\
\text { Zone IV }\end{array}$ \\
\hline $10 \mathrm{~mm}$ & 100 & 100 & 100 & 100 \\
\hline $4.75 \mathrm{~mm}$ & $90-100$ & $90-100$ & $90-100$ & $95-100$ \\
\hline $2.36 \mathrm{~mm}$ & $60-95$ & $75-90$ & $85-100$ & $95-100$ \\
\hline $1.18 \mathrm{~mm}$ & $30-70$ & $55-90$ & $75-100$ & $90-100$ \\
\hline $600 \mu$ & $15-34$ & $35-59$ & $60-79$ & $80-100$ \\
\hline $300 \mu$ & $5-20$ & $8-30$ & $12-40$ & $0-10^{*}$ \\
\hline $150 \mu$ & $0-10^{*}$ & $0-10^{*}$ & $0-10^{*}$ & \\
\hline
\end{tabular}

* For crushed stone sand the permissible limit is increased to $20 \%$

\subsection{Coarse Aggregate}

The crushed angular aggregate of $20 \mathrm{~mm}$ maximum size obtained from the local crushing plants is used as coarse aggregate in the present study. The physical properties of coarse aggregate such as specific gravity, bulk density, flakiness and elongation index are tested in accordance with IS: 2386-1963. The results of coarse aggregate are shown in the table 6 . The presence of elongated and flaky particles is $20 \%$ and $16.47 \%$ of the weight of the coarse aggregate. This shows that the coarse aggregate used in the concrete mixes is considered desirable as the indices are within $10-25 \%$. 
Table 6 : Physical Properties of Coarse Aggregate

\begin{tabular}{|c|c|c|c|}
\hline S.No & \multicolumn{2}{|c|}{ Properties } & Test Results \\
\hline 1 & \multicolumn{2}{|c|}{ Specific Gravity } & 2.71 \\
\hline & Bulk Density & Loose & $1597 \mathrm{Kg} / \mathrm{m} 3$ \\
\cline { 3 - 3 } 2 & $\mathrm{Kg} / \mathrm{m} 3$ & Compacted & $1725 \mathrm{Kg} / \mathrm{m} 3$ \\
\hline 3 & \multicolumn{2}{|c|}{ Elongation Index (\%) } & 20 \\
\hline 4 & \multicolumn{2}{|c|}{ Flakiness Index (\%) } & 16.47 \\
\hline
\end{tabular}

\subsection{Fly Ash}

In the present study of work, the Class F-fly ash is used, which is obtained from Vijayawada thermal power station in Andhra Pradesh. The specific surface area of fly ash is found to be $4750 \mathrm{~cm}^{2} / \mathrm{gm}$ by Blain's Permeability Apparatus. The typical composition of fly ash and chemical requirements are shown in table 7 and 8 respectively.

Table 7: Typical Oxide Composition of Fly Ash

\begin{tabular}{|c|c|c|}
\hline S.NO. & Constituent & Percentage \\
\hline 1 & $\mathrm{CaO}$ (Lime) & $0.7-3.6$ \\
\hline 2 & $\mathrm{SiO}_{2}$ (Silica) & $49-67$ \\
\hline 3 & $\mathrm{Al}_{2} \mathrm{O}_{3}$ (Alumina) & $16-28$ \\
\hline 4 & $\mathrm{Fe}_{2} \mathrm{O}_{3}$ (iron oxide) & $4-10$ \\
\hline 5 & $\mathrm{MgO}$ (magnesia) & $0.3-2.6$ \\
\hline 6 & $\mathrm{SO}_{3}($ Sulphur trioxide) & $0.1-1.9$ \\
\hline 7 & $\mathrm{Surface}^{2}$ area $\mathrm{m}^{2} / \mathrm{kg}$ & $230-600$ \\
\hline
\end{tabular}

Table 8: Chemical Requirement of Fly Ash (IS: 3812-part 1 2003)

\begin{tabular}{|c|c|c|c|}
\hline $\begin{array}{c}\text { S.N } \\
\mathrm{O} .\end{array}$ & $\begin{array}{c}\text { Characteristics } \\
\text { (Percent by mass) }\end{array}$ & $\begin{array}{c}\text { Minimum } \\
\text { Requirement in } \%\end{array}$ & $\begin{array}{c}\text { Composition of VTPS fly } \\
\text { ash in \% }\end{array}$ \\
\hline 1 & $\mathrm{SiO}_{2}+\mathrm{Al}_{2} \mathrm{O}_{3}+\mathrm{Fe}_{2} \mathrm{O}_{3}$ & 70 & 86.75 \\
\hline 2 & $\mathrm{SiO}_{2}$ & 35 & 54 \\
\hline 3 & Reactive Silica & 20 & 25 \\
\hline 4 & $\mathrm{MgO}$ & 5 & 7 \\
\hline 5 & $\mathrm{SO}_{3}$ (Sulphur trioxide) & 3 & 2.16 \\
\hline 6 & Available alkali as sodium oxide $\left(\mathrm{Na}_{2} \mathrm{O}\right)$ & 1.5 & 7.23 \\
\hline 7 & Loss of ignition & 5 & \\
\hline
\end{tabular}

\subsection{Ground Granulated Blast Furnace Slag}

Ground Granulated Blast Furnace Slag (GGBS) shown in fig 2 is a byproduct of the steel industry. Blast furnace slag is defined as "the non-metallic product consisting essentially of calcium silicates and other bases that is developed in a molten condition simultaneously with iron in a blast furnace". About $15 \%$ by mass of binders was replaced with GGBS.

Table: 9 Chemical Compositions of GGBS

\begin{tabular}{|c|l|c|}
\hline S.No & Constituent & Percentage \\
\hline 1 & Silicon dioxide $\left(\mathrm{SiO}_{2}\right)$ & 33.2 \\
\hline 2 & Alumina tri-oxide $\left(\mathrm{Al}_{2} \mathrm{O}_{3}\right)$ & 18.3 \\
\hline 3 & Ferric oxide $\left(\mathrm{Fe}_{2} \mathrm{O}_{3}\right)$ & 0.6 \\
\hline
\end{tabular}




\begin{tabular}{|c|l|c|}
\hline 4 & Calcium oxide $(\mathrm{Cao})$ & 32.9 \\
\hline 5 & Magnesium Oxide $(\mathrm{MgO})$ & 11.6 \\
\hline 6 & Sulphur tri-oxide $\left(\mathrm{SO}_{3}\right)$ & 1.0 \\
\hline 7 & Potassium oxide $\left(\mathrm{K}_{2} \mathrm{O}\right)$ & 0.91 \\
\hline 8 & Sodium oxide $\left(\mathrm{Na}_{2} \mathrm{O}\right)$ & 0.21 \\
\hline 9 & Chlorides $(\mathrm{Cl})$ & 0.006 \\
\hline
\end{tabular}

\begin{tabular}{|c|c|c|}
\hline S No & Characteristics & Result \\
\hline 1. & Colour & Dull white \\
\hline 2. & Fineness(Blaine's) $\mathrm{m}^{2} / \mathrm{kg}$ & 450 \\
\hline 3. & Specific Gravity & 2.91 \\
\hline 4. & Glass content percent & 93 \\
\hline 5. & Bulk Density kg/m³ & 1100 \\
\hline
\end{tabular}

\subsection{Water}

Water free from chemicals, oils and other forms of impurities is to be used for mixing of concrete as per IS: 456:2000.

\subsection{Geopolymers}

Geopolymers are member of the family of inorganic polymers, and are a chain structures formed on a backbone of $\mathrm{Al}$ and $\mathrm{Si}$ ions. The chemical composition of this geopolymer material is similar to natural zeolitic materials, but they have amorphous microstructure instead of crystalline (Palomo, Grutzeck et al. 1999; Xu and van (Deventer 2000).

\subsubsection{Constituents of Geopolymer}

\subsubsection{Source Materials}

Any material that contains mostly Silicon (Si) and Aluminium (Al) in amorphous form is a possible source material for the manufacture of geopolymer. Several minerals and industrial by-product materials have been investigated in the past. Low calcium fly ash (ASTM Class F) is preferred as a source material than high calcium (ASTM Class C) fly ash. The presence of calcium in high amount may interfere with the polymerisation process and alter the microstructure (Gourley 2003). On the nature of the source material, it was stated that the calcined source materials, such as fly ash, slag, calcined kaolin, demonstrated a higher final compressive strength when compared to those made using non-calcined materials, for instance kaolin clay, mine tailings, and naturally occurring minerals (Barbosa, MacKenzie et al. 2000). However, Xu and van Deventer (Xu and van Deventer 2002) found that using a combination of calcined (e.g. fly ash) and non-calcined material (e.g. kaolinite or kaolin clay and albite) resulted in significant improvement in compressive strength and reduction in reaction time. Natural Al-Si minerals have shown the potential to be the source materials for geopolymerisation, although quantitative prediction on the suitability of the specific mineral as the source material is still not available, due to the complexity of the reaction mechanisms involved (Xu and van Deventer 2000). Among the by-product materials, only fly ash and slag have been proved to be the potential source materials for making geopolymers. The other characteristics that influenced the suitability of fly ash to be a source material for geopolymers are the particle size, amorphous content, as well as morphology and the origin of fly ash.

\subsubsection{Alkaline Activators}

The most common alkaline activator used in geopolymerisation is a combination of sodium hydroxide $(\mathrm{NaOH})$ or potassium hydroxide $(\mathrm{KOH})$ and sodium silicate $\left(\mathrm{Na}_{2} \mathrm{SiO}_{3}\right)$ or potassium silicate (Davidovits 1999; Palomo, 
Grutzeck et al. 1999; Barbosa, MacKenzie et al. 2000; Xu and van Deventer 2000; Swanepoel and Strydom 2002; $\mathrm{Xu}$ and van Deventer 2002). The use of a single alkaline activator has been reported (Palomo, Grutzeck et al. 1999; Teixeira-Pinto, Fernandes et al. 2002), Palomo et al (1999) concluded that the type of activator plays an important role in the polymerisation process. Reactions occur at a high rate when the alkaline activator contains soluble silicate, either sodium or potassium silicate, compared to the use of only alkaline hydroxides. Xu and van Deventer (2000) confirmed that the addition of sodium silicate solution to the sodium hydroxide solution as the alkaline activator enhanced the reaction between the source material and the solution. Furthermore, after a study of the geopolymerisation of sixteen natural Al-Si minerals, they found that generally the $\mathrm{NaOH}$ solution caused a higher extent of dissolution of minerals than the $\mathrm{KOH}$ solution.

\subsubsection{Superplasticiser}

High range water reducing (Master Glenium B233) super plasticizer was used in the mixtures at the rate of $1.5 \%$ of fly ash to improve the workability of the fresh geopolymer concrete.

\subsection{General}

\section{EXPERIMENTAL INVESTIGATION}

An objective of this paper is aimed to investigate the compressive, tensile and flexural strength of low calcium fly ash (Class-F) and slag based geopolymer concrete for G50 which is equivalent to M50 grade of concrete. The alkaline solution used for the present study is combination of sodium silicate $\left(\mathrm{Na}_{2} \mathrm{SiO}_{3}\right)$ and sodium hydroxide ( $\mathrm{NaOH}$ in the range of 12 to 18 molarity). The ratio of $\mathrm{Na}_{2} \mathrm{SiO}_{3}$ to $\mathrm{NaOH}$ is 2.5 and $\mathrm{SiO}_{2}$ to $\mathrm{Na}_{2} \mathrm{O}$ is 2.09 has been used since the compressive strength is maximum at these ratios. The set of test specimens of 3 cubes of $150 \mathrm{~mm} * 150 \mathrm{~mm} * 150 \mathrm{~mm}, 3$ cylinders of $150 \times 300 \mathrm{~mm}$ and 3 prisms of $100 \times 100 \times 500 \mathrm{~mm}$ for each composition were cast for testing compressive, tensile and flexural strength respectively then after one day rest period, half of the specimens were cured in an oven at $60^{\circ} \mathrm{C}$ for 24 hours and for the remaining period cured under sun light until the testing is done and remaining half of the specimens were ambient cured. The specimens were tested on $3^{\text {rd }}, 7^{\text {th }}$ and $28^{\text {th }}$ day according to codal procedures. The results are tabulated and the required comparative study is done.

Table 11: Properties of Na2SiO3 Solution

\begin{tabular}{|l|l|}
\hline Specific gravity & 1.57 \\
\hline Molar mass & $122.06 \mathrm{gm} / \mathrm{mol}$ \\
\hline $\mathrm{Na}_{2} \mathrm{O}$ (by mass) & $14.35 \%$ \\
\hline $\mathrm{SiO} 2$ (by mass) & $30.00 \%$ \\
\hline Water (by mass) & $55.00 \%$ \\
\hline Weight ratio $\left(\mathrm{SiO}_{2}\right.$ to $\left.\mathrm{Na}_{2} \mathrm{O}\right)$ & 2.09 \\
\hline Molarity ratio & 0.97 \\
\hline
\end{tabular}

Table 12: Properties of $\mathrm{NaOH}$

\begin{tabular}{|l|l|}
\hline Molar mass & $40 \mathrm{gm} / \mathrm{mol}$ \\
\hline Appearance & White solid \\
\hline Density & $2.1 \mathrm{gr} / \mathrm{cc}$ \\
\hline Melting point & $318^{\circ} \mathrm{C}$ \\
\hline Boiling point & $1390^{\circ} \mathrm{C}$ \\
\hline $\begin{array}{l}\text { Amount of heat liberated } \\
\text { when dissolved in water }\end{array}$ & $266 \mathrm{cal} / \mathrm{gr}$ \\
\hline
\end{tabular}

Table 13: Mix Proportions for G50 grade of Geopolymer Concrete

\begin{tabular}{|l|c|}
\hline \multicolumn{1}{|c|}{ Grade of GPC } & G50 \\
\hline Fly ash $\left(\mathrm{Kg} / \mathrm{m}^{3}\right)$ & 410 \\
\hline Fine Aggregate $\left(\mathrm{Kg} / \mathrm{m}^{3}\right)$ & 554.4 \\
\hline Coarse Aggregate $\left(\mathrm{Kg} / \mathrm{m}^{3}\right)$ & 1293.6 \\
\hline
\end{tabular}




\begin{tabular}{|c|c|c|}
\hline \multirow{4}{*}{$\begin{array}{l}\mathrm{NaOH} \text { solids out of } \\
46.86 \mathrm{Kg} / \mathrm{m}^{3} \\
(\mathrm{M}) \text { concentration in } \\
\mathrm{Kg} / \mathrm{m}^{3}\end{array}$} & 12 & 16.92 \\
\hline & 14 & 18.93 \\
\hline & 16 & 20.81 \\
\hline & 18 & 22.49 \\
\hline \multicolumn{2}{|l|}{$\mathrm{Na}_{2} \mathrm{SiO}_{3}\left(\mathrm{Kg} / \mathrm{m}^{3}\right)$} & 117.14 \\
\hline \multicolumn{2}{|l|}{ Extra water $\left(\mathrm{Kg} / \mathrm{m}^{3}\right)$} & 45 \\
\hline \multicolumn{2}{|c|}{$\begin{array}{l}\text { Super plasticizer (GLENIUM)@ } \\
1.5 \%\left(\mathrm{Kg} / \mathrm{m}^{3}\right)\end{array}$} & 6.15 \\
\hline \multicolumn{2}{|c|}{ Ratio of mix proportions } & $1: 1.35: 3.16$ \\
\hline \multicolumn{2}{|c|}{ Liquid/binder ratio } & 0.40 \\
\hline \multicolumn{2}{|c|}{ Workability (mm) } & 50 \\
\hline
\end{tabular}

Table 14: Mix Proportions of OPC Controlled Concrete Expressed as Equivalent Proportions of GPC

\begin{tabular}{|c|c|}
\hline Grade of Concrete & M50 \\
\hline Cement $\left(\mathrm{Kg} / \mathrm{m}^{3}\right)$ & 410 \\
\hline Fine Aggregate $\left(\mathrm{Kg} / \mathrm{m}^{3}\right)$ & 554.4 \\
\hline Coarse Aggregate $\left(\mathrm{Kg} / \mathrm{m}^{3}\right)$ & 1293.6 \\
\hline 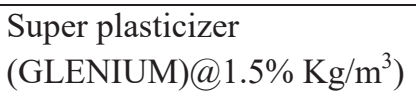 & 6.15 \\
\hline Ratio of mix proportions & $1: 1.35: 3.16$ \\
\hline $\mathrm{W} / \mathrm{C}$ ratio & 0.40 \\
\hline Workability (mm) & 50 \\
\hline
\end{tabular}

\subsection{Mixing and Casting of Geopolymer Concrete}

Geopolymer concrete can be manufactured by adopting the conventional concrete techniques used in the manufacture of Portland cement concrete. In the laboratory, the fly ash and the aggregates were first mixed together dry in a pan mixer for about three minutes. The alkaline liquid was mixed with the super plasticizer and extra water if any. The liquid component of the mixture was then added to the dry material and the mixing continued usually for another four minutes. The fresh concrete was cast and compacted by the usual methods used in the case of Portland cement concrete. The workability of the fresh concrete was measured by means of the conventional slump test. 


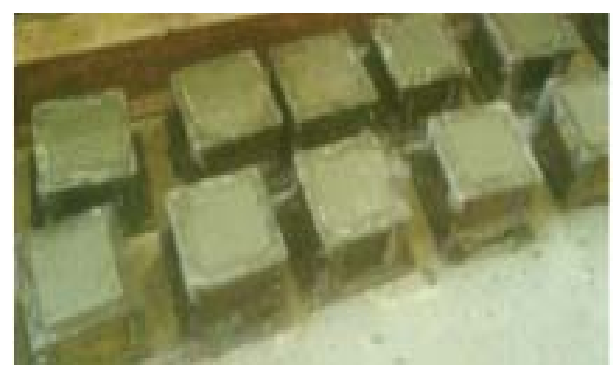

Fig. 1 Shows Cubes after Casting

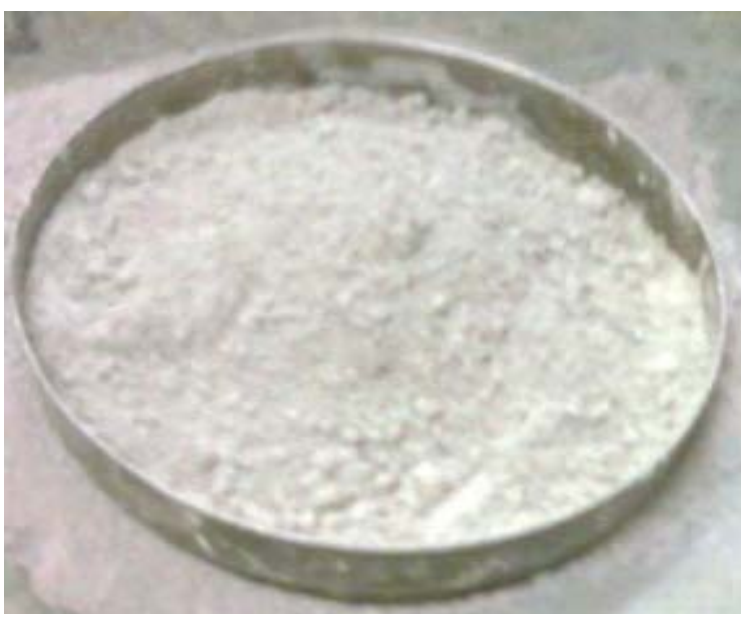

Fig. 2 Shows Ground Granulated Blast Furnace Slag (GGBS)

\subsection{Compressive Strength}

\section{TEST RESULTS}

After several trials of geopolymer mixes with different composition of fly ash and GGBS, an optimum compressive strength of the cubes is achieved at $85 \%$ fly ash and $15 \%$ GGBS is given in table 15 . From the table 15 and fig 3 it is observed that as the molarity of $\mathrm{NaOH}$ increases until $16 \mathrm{M}$, the compressive strength is increased then it is decreased. As the compressive strength of concrete is reached to target mean strength at $16 \mathrm{M}$ on $28^{\text {th }}$ day so an optimum compressive strength is considered at this molarity and further tests are also conducted based on this molarity.

Table 15: Compressive Strength (MPa) of G50 grade of Oven and Ambient cured Geopolymer Concrete

\begin{tabular}{|l|c|l|l|l|l|l|l|l|}
\hline & \multicolumn{3}{|c|}{$\begin{array}{c}\text { Geopolymer Concrete } \\
\text { (Ambient Curing) } \\
\text { 85\% FA +15\% GGBS }\end{array}$} & \multicolumn{3}{c|}{$\begin{array}{c}\text { Geopolymer Concrete } \\
\text { (Oven Curing) }\end{array}$} \\
& \multicolumn{3}{|c|}{ 85\% FA +15\% GGBS } \\
\hline Molarity & $12 \mathrm{M}$ & $14 \mathrm{M}$ & $\mathbf{1 6 M}$ & $18 \mathrm{M}$ & $12 \mathrm{M}$ & $14 \mathrm{M}$ & $\mathbf{1 6 M}$ & $18 \mathrm{M}$ \\
\hline 3 Days & 10.17 & 10.39 & $\mathbf{1 1 . 1 5}$ & 9.83 & 44.11 & 47.69 & $\mathbf{5 4 . 1 9}$ & 41.05 \\
\hline 7 Days & 22.57 & 24.41 & $\mathbf{2 6 . 8 9}$ & 21.98 & 47.08 & 50.62 & $\mathbf{5 5 . 6 3}$ & 44.42 \\
\hline 28 Days & 49.61 & 51.94 & $\mathbf{5 8 . 3 6}$ & 47.27 & 50.36 & 53.78 & $\mathbf{5 9 . 7 5}$ & 48.29 \\
\hline
\end{tabular}




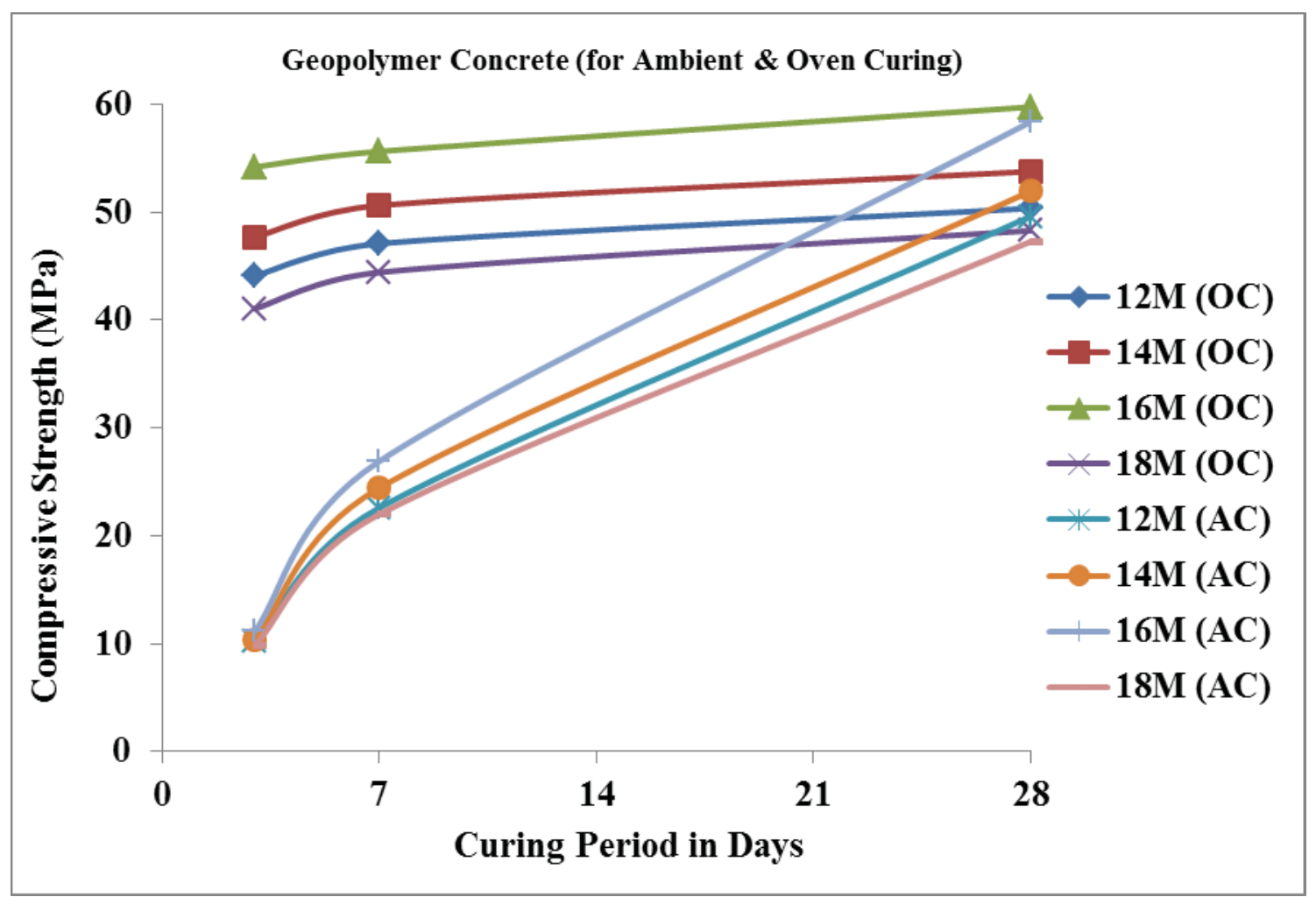

Fig. 3 shows Compressive Strength Vs Age of Concrete with various Molarity for Oven and Ambient Curing Table 16: Compressive Strength (MPa) of G50 equivalent to M50 grade of Concrete

\begin{tabular}{|l|c|c|c|}
\hline & G50 & G50 & M50 \\
(Ambient Curing) & (Oven Curing) & (Controlled Concrete) \\
\hline 3 Days & 11.15 & $\mathbf{5 4 . 1 9}$ & 28.92 \\
\hline 7 Days & 26.89 & $\mathbf{5 5 . 6 3}$ & 41.07 \\
\hline 28 Days & 58.36 & $\mathbf{5 9 . 7 5}$ & 58.42 \\
\hline
\end{tabular}

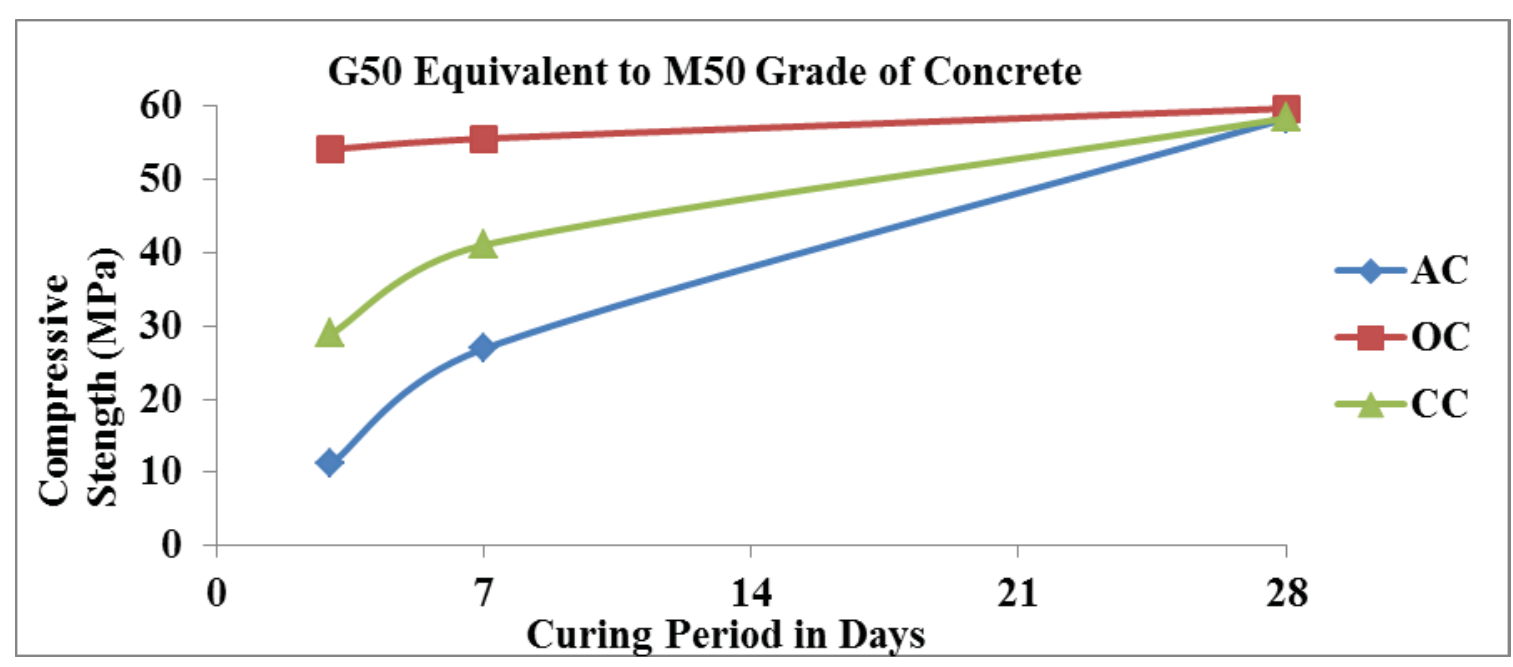

Fig. 4 shows Compressive Strength Vs Age of Concrete for various curing methods

4.2 Split Tensile Strength 
After several trials of geopolymer mixes with different composition of fly ash and GGBS, an optimum compressive strength of the cubes is achieved at $85 \%$ fly ash and 15\% GGBS. Based on this composition the cylindrical specimens of $150 \times 300 \mathrm{~mm}$ were cast and tested on $3^{\text {rd }}, 7^{\text {th }}$ and $28^{\text {th }}$ day. From the table 17 and fig 5 it is observed that split tensile strength of geopolymer concrete is slightly lower than the controlled concrete.

Table 17: Split Tensile Strength (MPa) of G50 of Geopolymer and M50 of Controlled Concrete

\begin{tabular}{|l|c|c|c|}
\hline & $\begin{array}{c}\text { G50 } \\
\text { (Ambient Curing) }\end{array}$ & $\begin{array}{c}\text { G50 } \\
\text { (Oven Curing) }\end{array}$ & $\begin{array}{c}\text { M50 } \\
\text { (Controlled Concrete) }\end{array}$ \\
\hline 3 Days & 0.68 & 3.13 & 2.12 \\
\hline 7 Days & 1.57 & 3.20 & 2.77 \\
\hline
\end{tabular}

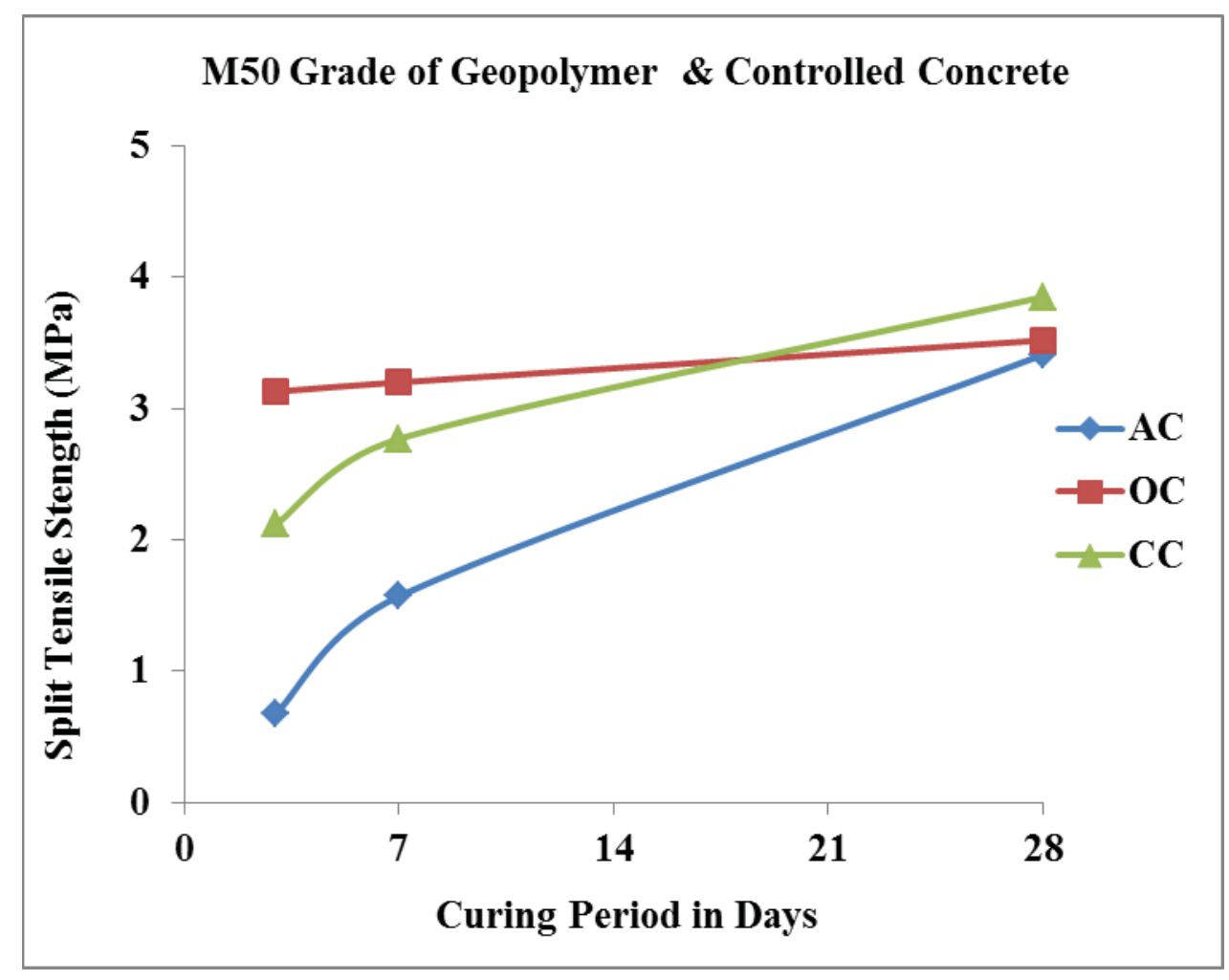

\subsection{Flexural Strength}

Fig. 5 shows Split Tensile Strength Vs Age of Concrete for various curing methods

After several trials of geopolymer mixes with different composition of fly ash and GGBS, an optimum compressive strength of the cubes is achieved at $85 \%$ fly ash and 15\% GGBS. Based on this composition the prism specimens of $100 \times 100 \times 500 \mathrm{~mm}$ were cast and tested on $3^{\text {rd }}, 7^{\text {th }}$ and $28^{\text {th }}$ day. From the table 18 and fig 6 it is observed that there is no much difference in flexural strength of geopolymer concrete compared to controlled concrete.

Table 18: Flexural Strength (MPa) of G50 of Geopolymer and M50 of Controlled Concrete

\begin{tabular}{|l|c|c|c|}
\hline & $\begin{array}{c}\text { G50 } \\
\text { (Ambient Curing) }\end{array}$ & $\begin{array}{c}\text { G50 } \\
\text { (Oven Curing) }\end{array}$ & $\begin{array}{c}\text { M50 } \\
\text { (Controlled Concrete) }\end{array}$ \\
\hline 3 Days & 1.17 & 4.85 & 2.99 \\
\hline 7 Days & 2.52 & 5.19 & 4.01 \\
\hline 28 Days & 5.59 & 5.71 & 5.65 \\
\hline
\end{tabular}




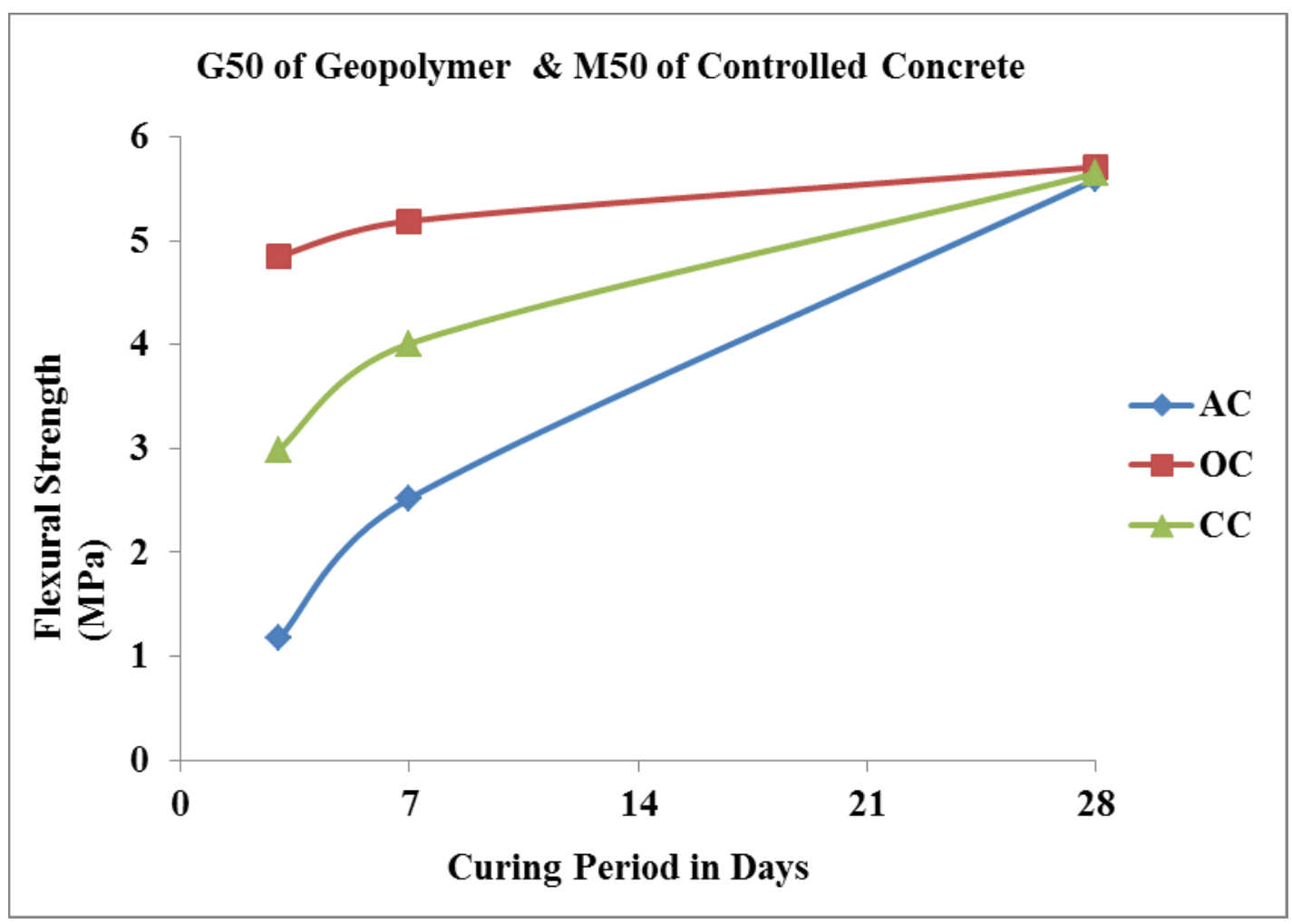

Fig. 6 shows Flexural Strength Vs Age of Concrete for various curing methods

\section{CONCLUSIONS}

The following specific conclusions can be drawn from the present experimental investigation

i. It is clear that as the molarity of $\mathrm{NaOH}$ increases from 12 to $16 \mathrm{M}$, the compressive strength is increased and from 16 to $18 \mathrm{M}$ it is decreased.

ii. It is observed that an optimum compressive strength of the cubes is achieved at $85 \%$ fly ash and $15 \%$ GGBS at 16 molarity since the compressive strength is reached to target mean strength on the $28^{\text {th }}$ day.

iii. The attainment of compressive strength is very early in the case of oven cured geopolymer concrete compared to controlled concrete by $87 \%, 35 \%$ on $3^{\text {rd }}$ and $7^{\text {th }}$ day respectively.

iv. It is observed that split tensile strength of geopolymer concrete is slightly lower than the controlled concrete.

v. It can be said that there is no much difference in flexural strength of geopolymer concrete compared to controlled concrete.

\section{REFERENCES}

[1] J. Davidovits, "Geopolymer chemistry and properties," in Proc.Geopolymer '88, First European Conference on Soft Mineralogy, The Geopolymer Institute, Compiegne, France, 1988, pp. 25-48.

[2] Kolli Ramujee and Dr.M.Potharaju, "Development of Mix Design for Low Calcium based Geopolymer concrete in Ordinary, Standard and High Strength Grades", ICI Journal, July-September, 2013, pp 29-34.

[3] B.Vijaya Rangan, "Geopolymer Concrete for Environmental Protection", The Indian Concrete Journal, April-2014, pp. 41-59.

[4] D. Hardjito, S. E. Wallah, and B. V. Rangan, "Study on engineering properties of fly ash-based geopolymer concrete," Journal of the Australasian Ceramic Society, vol. 38, no. 1, pp. 44-47, 2002.

[5] D. Hardjito, S. E. Wallah, D. M. J. Sumajouw, and B. V. Rangan, "Factors influencing the compressive strength of fly ash-based geopolymer concrete," Civil Engineering, High performance Concretes and Smart Materials Dimension (Dimensi Teknik Sipil), vol. 6, no. 2, pp. 88-93, 2004.

[6] D. Hardjito, S. E. Wallah, D. M. J. Sumajouw, and B. V. Rangan, "On the development of flyash-based geopolymer concrete," ACI Materials Journal, vol. 101, no. 6, pp. 467-472, 2004. 
[7] E. I. D. Lota, E. N. allouche, and S. Vaidya "Mechanical properties of Flyash based Geopolymer concrete, " ACI Materials Journal, vol. 108, no. 3, pp. 300-306, May-June 2011.

[8] D. Hardjito, S. E.Wallah, D. M. J. Sumajouw, and B. V. Rangan, "Fly ash-based geopolymer concrete," Australian Journal of Structural Engineering, vol. 6, no. 1, pp. 77-86, 2005.

[9] D. M. J. Sumajouw, D. Hardjito, S. E. Wallah, and B. V. Rangan, "Behaviour and strength of geopolymer concrete columns," in Proc.18th Australasian Conference on the Mechanics of Structures and Materials, Perth, Australia, Ed. A.A. Balkema, vol. 1, 2004, pp.175-180.

[10] A. M. Neville, Properties of Concrete, Fourth and Final ed., Pearson Education, Longman Group Essex, England, 2000.

[11] Method of Test for Aggregate Concrete, Bureau of Indian Standards, IS-2386-1963.

[12] Specification for Coarse and Fine Aggregates from the Natural Sources for Concrete, Bureau of Indian Standards, IS: 383-1970.

[13] Method for Physical Tests for Hydrated Cement, Bureau of Indian Standards, IS: 4031 - 1988.

[14] Method of Test for Strength of Concrete, Bureau of Indian Standards, IS: 516-1959.

[15] J. Davidovits, "Soft mineralogy and geopolymers," in Proc.Geopolymer '88, First European conference on Soft Mineralogy, The Geopolymer Institute, Compiegne, France, 1988, pp. 19-24.

[16] J. Davidovits, "Global warming impact on the cement and aggregates industries," World Resource Review, vol. 6, no. 2, pp. 263-278, 1994. 